

Journal homepage: http://www.journalijar.com

Journal DOI: 10.21474/IJAR01

INTERNATIONAL JOURNAL

OF ADVANCED RESEARCH

RESEARCH ARTICLE

\title{
ETHNOBOTANICAL STUDY OF MEDICINAL PLANTS USED BY TRIBALS IN ANANTAPUR DISTRICT, ANDHRA PRADESH, INDIA.
}

\author{
S Raja Sekhar* \\ Division of Biological Sciences, Bangalore University, Bengaluru-560056, Karnataka, India.
}

\section{Manuscript Info}

Manuscript History:

Received: 18 May 2016

Final Accepted: 19 June 2016

Published Online: July 2016

Key words: Medicinal plants, Anantapur district.

*Corresponding Author

S Raja Sekhar.

\section{Abstract}

The present study deals with the study of some of the medicinal plants were used by sugali tribes of the Anantapur district, Andhra Pradesh, India. These tribes are depending on the medicinal plants for traditional health care. 25 Medicinal plants were identified and botanical name, local name, family, habitat, part of plant used, mode of consumption, disease cured and preparation method are represented.

Copy Right, IJAR, 2016,. All rights reserved.

\section{Introduction:-}

India is an identified mega diverse country, rich in biodiversity and associated traditional knowledge. In floral diversity, India ranks tenth in the world and fourth in Asia (Sanjay et al., 2015). In India about two lakh villages are in forest area (Aggarwal et al., 2009). India has the second largest tribal population in the world after Africa (Mukherkee et al., 2013). The Anantapur District is a district in the Rayalaseema region of Andhra Pradesh, India. The district headquarters is located at Anantapur city. As of 2011 Census, the district had a population of 4,083,315 of which 28.095 is urban and literacy rate of 64.28\%. It is the largest district in terms of area in Andhra Pradesh and $7^{\text {th }}$ largest district in India respectively.

This region has been dominated by nomadic sugali tribes. The forest regions are inhabited by twenty thousand sugali tribal people. The sugalis are inhabiting this place were nature worshippers originally, and they worship Champaka tree (Michelia champaca), called Dodda Sampige in the local language (Ganeshaiah et al., 1998).

Our present aim to 1. Document plant species that were utilized for medicinal purposes among the tribal people of the sugali tribes. 2. Document human diseases, traditional plant remedies, methods of preparation and mode of administration.

\section{Methodology:-}

Periodic field studies were carried out in different villages of Anantapur district. Normally tribal peoples are hesitating to talk with strangers and very conservative regarding providing information. They feel if they disclose medicinal property of a plant that plant will be lost forever. However, information gathered from tribal's, local vaidyas, medicine men and women village elders through personal communication and questionnaire.

Questionnaires were used to collect information from the tribal people. Questionnaires consists name, sex, age, vernacular name of the plant, the parts and properties that were used, mode of preparation, approximate doses and mode of administration. 
The collected plant species were identified with the help of different published data and flora.

The medicinal plants are categorized disease wise under each section arranged in the alphabetical order of plant species name followed by family name, local name, part(s) used and mode of administration(i.e. decoction, paste, powder and juice),for reported plant species.

\section{Discussion:-}

The present investigation provides an ethno botanical data of the 25 medicinal plants used by the sugali tribal people of Anantapur district, Andhra Pradesh, India.. The medicinal plant botanical name, local name, family, habitat, part of plant used, mode of consumption, disease cured and preparation method are represented in the table (See table). The majority of plants species belong to families Fabaceae, Mimosaceae, Amarantahceae and Rubiaceae.

The knowledge and usage of herbal medicine for the treatment of various human diseases and disorders in local villages is still a major part of tribal life. Allopathic medicines are expensive and there is no side effect in comparison to the traditional medicine. This indicates the reason for the dependence of tribal peoples on traditional medicine.

The common diseases of this area are Cough, cold, Headache, Dysentery, Fever and Jaundice. These tribes are consuming the highly nutritious forest products such as honey, tubers fruits and etc. They won't suffer from major diseases like, Diabetes, Tuberculosis, Measles and Mumps. Many of the tribal peoples are using plants for disease cure. There is a need to establish herbal drug centers from newly identified medicinal plants for collecting, processing and preparation of herbal medicine and to improving the life and economy of the local tribal and rural peoples. 


\begin{tabular}{|c|c|c|c|c|c|c|c|c|}
\hline \multicolumn{9}{|c|}{ Its: } \\
\hline S.No & Botanical name & $\begin{array}{l}\text { Local } \\
\text { name }\end{array}$ & Family & Habit & $\begin{array}{l}\text { Part of } \\
\text { plant } \\
\text { used }\end{array}$ & $\begin{array}{l}\text { Mode of } \\
\text { consumption }\end{array}$ & $\begin{array}{l}\text { Disease } \\
\text { cured }\end{array}$ & Preparation method \\
\hline 1 & $\begin{array}{l}\text { Acampe praemorsa (ROXB.) } \\
\text { BLATT. \& MCCANN }\end{array}$ & $\begin{array}{l}\text { Marabale } \\
\text { soppu }\end{array}$ & Orchidaceae & Shrub & Leaves & $\begin{array}{l}\text { External } \\
\text { application }\end{array}$ & Mouth ulcer & $\begin{array}{l}\text { The leaves are made into } \\
\text { paste and mixed with } \\
\text { coconut oil and applied }\end{array}$ \\
\hline 2 & Achyranthes aspera L. & Uttarani & Amaranthaceae & Herb & Roots & Liquid/tonic & Piles & $\begin{array}{l}\text { The root is made into } \\
\text { paste and add some water } \\
\text { and consumed. }\end{array}$ \\
\hline 3 & $\begin{array}{l}\text { Aegle marmelos }(L) \text { CORREA } \\
\text { EX.SCHULTZ }\end{array}$ & Bilipatri & Rutaceae & Tree & Leaves & $\begin{array}{l}\text { External } \\
\text { application }\end{array}$ & $\begin{array}{l}\text { Headache, } \\
\text { Common } \\
\text { cold }\end{array}$ & $\begin{array}{l}\text { The leaves are pasted } \\
\text { with water and applied on } \\
\text { Forehead for headache) } \\
\text { and consumed for } \\
\text { (common cold) }\end{array}$ \\
\hline 4 & Albizia amara(ROXB.) BOIVIN & Bayibasale & Fabaceae & Tree & $\begin{array}{l}\text { Roots } \\
\text { leaves }\end{array}$ & Curry & Ulcers & $\begin{array}{l}\text { The root or leaves is } \\
\text { boiled with pulses (dal) } \\
\text { and made into curry. }\end{array}$ \\
\hline 5 & Albizia odoratissima (L.F.)BENTH. & Bilvaara & Mimosaceae & Tree & Root & $\begin{array}{l}\text { External } \\
\text { application }\end{array}$ & $\begin{array}{l}\text { To prevent } \\
\text { hair loss }\end{array}$ & $\begin{array}{l}\text { Paste of root is applied } \\
\text { once in a day for fifteen } \\
\text { days. }\end{array}$ \\
\hline 6 & $\begin{array}{l}\text { Alternanthera sessilis (L.) R.BR.EX } \\
\text { DC. }\end{array}$ & $\begin{array}{l}\text { Honagon } \\
\text { esoppu }\end{array}$ & Amarantahceae & Herb & Leaves & Curry & Jaundice & $\begin{array}{l}\text { A curry or fry is prepared } \\
\text { with the leaves and } \\
\text { consumed }\end{array}$ \\
\hline 7 & Anisochilus carnosus WALL & Doddipatri & Lamiaceae & Shrub & Leaves & Liquid/tonic & $\begin{array}{l}\text { Common } \\
\text { cold, throat } \\
\text { infection }\end{array}$ & $\begin{array}{l}\text { leaves are boiled with } \\
\text { water and extract is taken } \\
\text { as a drink or the leaves } \\
\text { are added to tea and } \\
\text { consumed. }\end{array}$ \\
\hline 8 & Arisaema tortuosum SCHOTT & Marigida & Aracease & Shrub & Leaves & $\begin{array}{l}\text { External } \\
\text { application }\end{array}$ & Fever & $\begin{array}{l}\text { Leaves are made into } \\
\text { paste with water and } \\
\text { applied all over the body. }\end{array}$ \\
\hline
\end{tabular}




\begin{tabular}{|c|c|c|c|c|c|c|c|c|c|}
\hline S.No & Botanical name & & Local name & Family & Habit & $\begin{array}{l}\text { Part } \\
\text { of } \\
\text { plant } \\
\text { used }\end{array}$ & $\begin{array}{l}\text { Mode of } \\
\text { consumpti } \\
\text { on }\end{array}$ & $\begin{array}{l}\text { Disease } \\
\text { cured }\end{array}$ & Preparation method \\
\hline 9 & Aristolochia indica L. & & $\begin{array}{l}\text { Nanjinabaer } \\
\mathrm{u}\end{array}$ & $\begin{array}{l}\text { Aristolochiace } \\
\text { ae }\end{array}$ & $\begin{array}{l}\text { Climb } \\
\text { er }\end{array}$ & Roots & $\begin{array}{l}\text { External } \\
\text { application }\end{array}$ & Head ache & $\begin{array}{l}\text { Leaves are made into paste with } \\
\text { water and on forehead. }\end{array}$ \\
\hline 10 & $\begin{array}{l}\text { Asparagus racemosus } \\
\text { Willd. }\end{array}$ & & Aheru balli & Liliaceae & $\begin{array}{l}\text { Climb } \\
\text { er }\end{array}$ & $\begin{array}{l}\text { Root/ } \\
\text { tuber }\end{array}$ & Raw tuber & $\begin{array}{l}\text { for } \\
\text { pregnancy }\end{array}$ & $\begin{array}{l}\text { The tuber is washed and consumed } \\
\text { directly }\end{array}$ \\
\hline 11 & Bombax ceiba L. & & $\begin{array}{l}\text { Yelelevalada } \\
\text { mara }\end{array}$ & Bombaceae & Tree & Bark & $\begin{array}{l}\text { Liquid/ } \\
\text { tonic }\end{array}$ & $\begin{array}{l}\text { White and } \\
\text { red } \\
\text { discharge }\end{array}$ & $\begin{array}{l}\text { The bark along with other } \\
\text { ingredients } \\
\text { i.e.,Dhrakshi,kallunara,karijeerie,g } \\
\text { erpappu and kallu uppu are added } \\
\text { in equal proportion and crushed } \\
\text { thoroughly(without water). Then } \\
\text { add this mix into Kellengu (red } \\
\text { coconut) and store overnight. Mix } \\
\text { well and consume early morning. }\end{array}$ \\
\hline 12 & $\begin{array}{l}\text { Calotropis gigantea } \\
\text { (L.) R.BR. }\end{array}$ & & Aekki gida & $\begin{array}{l}\text { Asclepiadacea } \\
\text { e }\end{array}$ & Shrub & $\begin{array}{l}\text { Leave } \\
\mathrm{s}\end{array}$ & $\begin{array}{l}\text { External } \\
\text { application }\end{array}$ & snake bite & $\begin{array}{l}\text { Plant latex is mixed with } \\
\text { asafoetida (ingu) grind well and } \\
\text { applied on the spot. }\end{array}$ \\
\hline 13 & Capparis grandis $L$. & & Tottula & Capparaceae & Shrub & $\begin{array}{l}\text { Leave } \\
\mathrm{s}\end{array}$ & $\begin{array}{l}\text { External } \\
\text { application }\end{array}$ & swelling & $\begin{array}{l}\text { Half-one kg leaves are boiled in } 1 \\
\text { bucket water and bath is taken } 3 \\
\text { days to cure swellings }\end{array}$ \\
\hline 14 & Carissa carandas $\mathrm{L}$ & & $\begin{array}{l}\text { Karavadimar } \\
\text { a }\end{array}$ & Apocynaceae & Shrub & Bark & $\begin{array}{l}\text { External } \\
\text { application }\end{array}$ & $\begin{array}{l}\text { Pigmentati } \\
\text { on }\end{array}$ & $\begin{array}{l}\text { The bark is made into paste and } \\
\text { applied }\end{array}$ \\
\hline 15 & Cassia fistula $\mathrm{L}$ & & Kakke mara & $\begin{array}{l}\text { Caesalipini } \\
\text { aceae }\end{array}$ & Tree & $\begin{array}{l}\text { Leave } \\
\mathrm{s}\end{array}$ & $\begin{array}{l}\text { Liquid/ } \\
\text { tonic }\end{array}$ & $\begin{array}{l}\text { Tumors in } \\
\text { stomach }\end{array}$ & $\begin{array}{l}\text { Leaves were collecting from the } \\
\text { tree and make it past by grinding } \\
\text { then intake by oral }\end{array}$ \\
\hline S.No & Botanical name & $\begin{array}{l}\text { Local } \\
\text { name }\end{array}$ & Family & Habit & $\begin{array}{l}\text { Part of } \\
\text { plant used }\end{array}$ & \multicolumn{2}{|c|}{$\begin{array}{l}\text { Mode of } \\
\text { consumption }\end{array}$} & $\begin{array}{l}\text { Disease } \\
\text { cured }\end{array}$ & Preparation method \\
\hline 16 & $\begin{array}{l}\text { Catunaregum spinosa } \\
\text { THUNB. }\end{array}$ & $\begin{array}{l}\text { Maggare } \\
\text { kai }\end{array}$ & Rubiaceae & Shrub & Fruits & \multicolumn{2}{|c|}{$\begin{array}{l}\text { External } \\
\text { application }\end{array}$} & $\begin{array}{l}\text { Pimples, } \\
\text { acne }\end{array}$ & $\begin{array}{l}\text { The fruits are pasted and } \\
\text { applied on face }\end{array}$ \\
\hline 17 & Cicca acida MERRILL & $\begin{array}{l}\text { Kirumail } \\
\text { i }\end{array}$ & $\begin{array}{l}\text { Euphorbiace } \\
\text { ae }\end{array}$ & Tree & Root & \multicolumn{2}{|c|}{ Liquid/tonic } & AIDS & $\begin{array}{l}\text { The root is mixed with } \\
\text { Jajikai, badami, kallusakkare, } \\
\text { kallunara and made into } \\
\text { paste. This extract is } \\
\text { consumed } 3 \text { times a day for } \\
\text { 3days }\end{array}$ \\
\hline
\end{tabular}




\begin{tabular}{|c|c|c|c|c|c|c|c|c|}
\hline 18 & $\begin{array}{l}\text { Citrullus colocynthis (L.) } \\
\text { SCHRADER }\end{array}$ & $\begin{array}{l}\text { Tumtika } \\
\text { yi }\end{array}$ & $\begin{array}{l}\text { Cucurbitace } \\
\text { ae }\end{array}$ & Tree & $\begin{array}{l}\text { fruit and } \\
\text { seed }\end{array}$ & Oral & $\begin{array}{l}\text { Jaundice } \\
\text { and } \\
\text { scorpion } \\
\text { sting }\end{array}$ & $\begin{array}{l}\text { fruit are used in jaundice. } \\
\text { Seed oil is used in scorpion } \\
\text { bite. }\end{array}$ \\
\hline 19 & Dalbergia sissoo $\mathrm{ROXB}$ & $\begin{array}{l}\text { Agurima } \\
\text { ra }\end{array}$ & Fabaceae & Tree & Bark & Liquid/tonic & Dysentery & $\begin{array}{l}\text { The bark is pasted and the } \\
\text { extract is consumed }\end{array}$ \\
\hline 20 & $\begin{array}{l}\text { Decalepis hamiltonii WIG } \\
\text { HT \& ARN. }\end{array}$ & $\begin{array}{l}\text { Magali } \\
\text { beru }\end{array}$ & $\begin{array}{l}\text { Asclepiadac } \\
\text { eae }\end{array}$ & & Root & Pickle & $\begin{array}{l}\text { To reduce } \\
\text { body heat }\end{array}$ & $\begin{array}{l}\text { A pickle is prepared and } \\
\text { stored }\end{array}$ \\
\hline 21 & $\begin{array}{l}\text { Dendrophthoe falcata } \\
\text { (L.F) ETTING. }\end{array}$ & Sigare & Lorthanceae & Shrub & Leaf & $\begin{array}{l}\text { External } \\
\text { application }\end{array}$ & $\begin{array}{l}\text { Bone } \\
\text { fracture }\end{array}$ & $\begin{array}{l}\text { Fresh leaves are tide on } \\
\text { fractured born for } 7 \text { days }\end{array}$ \\
\hline 22 & $\begin{array}{l}\text { Dichrostachys cinerea } \\
\text { WIGHT \& ARN. }\end{array}$ & Odavare & Mimosaceae & Tree & Roots & $\begin{array}{l}\text { External } \\
\text { application }\end{array}$ & Body pains & $\begin{array}{l}\text { The roots are pasted with } \\
\text { water and applied all over the } \\
\text { body }\end{array}$ \\
\hline 23 & $\begin{array}{l}\text { Elettaria cardamomum } \mathrm{M} \\
\text { ATON }\end{array}$ & Karilakki & $\begin{array}{l}\text { Zingiberacea } \\
\text { e }\end{array}$ & Herb & Leaves & $\begin{array}{l}\text { External } \\
\text { application/tonic }\end{array}$ & Anemia & $\begin{array}{l}\text { The leaves are boiled in milk } \\
\text { and consumed or paste Is } \\
\text { applied externally }\end{array}$ \\
\hline
\end{tabular}

\begin{tabular}{|c|c|c|c|c|c|c|c|c|}
\hline S.No & Botanical name & Local name & Family & Habit & $\begin{array}{l}\text { Part of } \\
\text { plant } \\
\text { used }\end{array}$ & $\begin{array}{l}\text { Mode of } \\
\text { consumption }\end{array}$ & Disease cured & Preparation method \\
\hline 24 & Embelia ribes BURM.F & Vayuvilnga & Myrsinaceae & Shrub & Roots & Liquid/tonic & $\begin{array}{l}\text { Indigestion, } \\
\text { gastric } \\
\text { problems }\end{array}$ & $\begin{array}{l}\text { The roots are pasted } \\
\text { and made into a drink } \\
\text { along with pepper, } \\
\text { garlic, salt and jeer } \\
\text { (cumin seeds) and } \\
\text { consumed. }\end{array}$ \\
\hline 25 & $\begin{array}{l}\text { Emblica officinalis GAER } \\
\text { TN. }\end{array}$ & Nelikai & Euphorbiaceae & Tree & Fruit & Paste & $\begin{array}{l}\text { Common cold, } \\
\text { cough }\end{array}$ & $\begin{array}{l}\text { The fruit is mixed with } \\
\text { ginger and } 2 \text { drops of } \\
\text { honey, made into paste } \\
\text { and consumed }\end{array}$ \\
\hline
\end{tabular}




\section{References:-}

1. Sanjay Singh Chauhan and Avinash Tiwari., 2015. Vegetational analysis and seasonal aspectation of tropical dry deciduous forest of Madhav National Park, Shivpuri.(M.P.) International Journal of Scientific and Research Publications 5, 1-5.

2. Aggarwal A, Paul V, and Das S. 2009. Forest Resources: Degradation, Livelihoods, and Climate Change, pp. 91-108 In Datt D and S. Nischal, 2009, Looking Back to Change Track. New Delhi: TERI pp 219

3. Mukherkee Sourav, Kulkarni Omkar, Deokule Subhash, Gadgil Swati, Harsulkar Abhay \& Jagtap Suresh. 2013. Oil extraction from medicinal plants by Pawra tribe of Nandurbar district (Maharastra): Value addition and sustainable utilization with the aid of Ayurved. Indian journal of Traditinal Knowledge 12, 272-276.

4. Ganeshaiah, K. N., R. Uma Shaanker and K. S. Bawa. (1998) Biligiri Rangaswamy Temple Wildlife Sanctuary: Natural history, biodiversity and conservation. ATREE. 